\title{
Литологические особенности пород продуктивного горизонта Ю1 Малореченского нефтяного месторождения (Томская область)
}

\author{
С.Х. Бешлеев ${ }^{a}$, О.Е. Кочнева ${ }^{b}$
}

аПермский государственный национальный исследовательский университет, 614990, Пермь, ул.Букирева,15. E-mail: selim.beshli@gmail.com

鸟ермский национальный исследовательский политехнический университет, 614990, Пермь, Комсомольский пр., 29. E-mail: kochnevaoe@ mail.ru (Статья поступила в редакцию 21 сентября 2015 г.)

\begin{abstract}
Изучены геологическое строение и продуктивный горизонт $Ю_{1}$ Малореченского месторождения. Установлены литологическая изменчивость отложений и петрографические особенности пород, слагающих верхнеюрский разрез. Горизонт $Ю_{1}$ неоднороден, и пласты хорошо выделяются по каротажным данным. На некоторых участках происходит слияние пластов, а местами они разделены глинистыми и глинисто-углистыми пропластками.

Ключевые слова: продуктивный пласт, корреляциия, нефтенасыщенность, литология, анализ.
\end{abstract}

DOI: $10.17072 /$ psu.geol.29.82

\section{Введение}

Нефтяная промышленность Томской области достигла значительного уровня добычи нефти и в последующем будет не только удерживать, но и повышать его. Перед геологами-нефтяниками Томской области поставлены задачи по приросту запасов и открытию новых месторождений. Открытые за последние годы месторождения нефти по запасам относятся к категории мелких [1]. К таким месторождениям относится Малореченское, расположенное в Александровском районе Томской области (рис. 1).

В его геологическом разрезе принимают участие породы палеозойского фундамента, сложенного плотными известняками и терригенными отложениями мезозойско-кайнозойского осадочного чехла.
Малореченское месторождение расположено в пределах восточной части Нижневартовского антиклинория, осложняющего центральную часть ЗападноСибирской плиты $[6,7]$. По отложениям чехла антиклинорию соответствует Нижневартовский свод - положительная структура первого порядка, осложненная Малореченским куполовидным поднятием [2], к северо-восточной части которого приурочено нефтяное месторождение.

Оно открыто скважиной $117 \mathrm{p}$, пробуренной в 1965 г. в присводовой части Малореченской структуры, с 1985 г. введено в разработку. Продуктивными являются пласты $Ю_{1}{ }^{1}$ и $Ю_{1}^{2}$ верхнеюрского горизонта $Ю_{1}$.

Залежи нефтяные, пластово-сводового типа [4]. По количеству запасов место- 
рождение классифицируется как среднее, по геологическому строению - сложное.

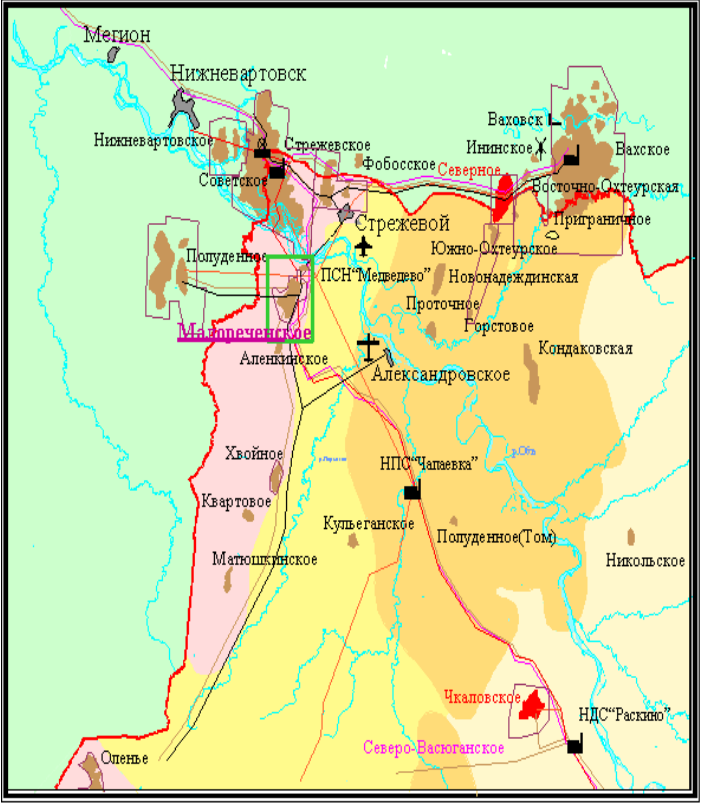

Рис. 1. Обзорная карта района Малореченского месторождения (по Н.В. Гейлю, 1988)

Актуальность исследований связана с продуктивностью пластов и их сложным геологическим строением.

В работе были проведены следующие исследования:

1. Макроскопическое описание керна и построение литологической колонки.

2. Корреляция верхнеюрских отложений по линиям I-I и II-II, секущим месторождение с севера на юг и с запада на восток по данным геофизических исследований скважин и макроскопического описания керна.

3. Выделение и индексация продуктивных пластов и реперных горизонтов.

4.Петрографический анализ породколлекторов и пород-флюидоупоров.

\section{1. Корреляции и индексация верхнеюр- ских отложений}

По данным каротажных диаграмм проведена корреляция верхнеюрских отложений по линиям I-I и II-II, секущим месторождение с севера на юг и с запада на восток (рис. 2), и проведена индексация выделенных пластов (рис. 3, 4).

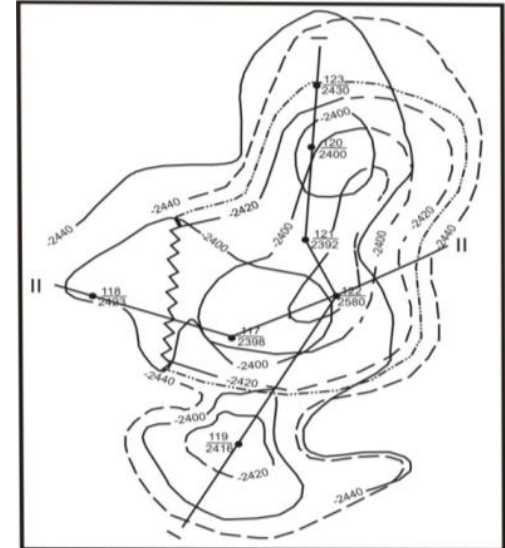

Рис. 2. Структурная карта горизонта $Ю_{1} u$ положение линий разрезов (по Н.В. Гейлю, 1988)

В эталонном разрезе горизонта $Ю_{1}$ Малореченской площади хорошо выделяются основные стратиграфические элементы. К ним относятся трансгрессивные алевритоглинистые отложения нижневасюганской подсвиты; отложения верхневасюганской подсвиты: регрессивная толща пласта $Ю_{1}{ }^{4}$, регрессивная глинистопесчаная толща пласта $\mathrm{Ю}_{1}{ }^{3}$, трансгрессивно-регрессивная песчаная и участками алевритоглинистая толща пласта $\mathrm{Ю}_{1}{ }^{2}$ и трансгрессивные: песчано-глинистая толща пласта $Ю_{1}{ }^{1}$, преимущественно глинисто-алевритовый пласт $\mathrm{Ю}_{1}{ }^{0}$, глинистые отложения георгиевской и аргиллиты баженовской свиты (рис. 3, 4).

Последовательность чередования этих свит характеризует смену обстановок осадконакопления от мелководно-морской - нижняя подсвита васюганской свиты до прибрежно-морской (пласты $Ю_{1}^{4}, Ю_{1}{ }^{2}$, $\left.Ю_{1}^{1}\right)$, прибрежно-континентальной $\left(Ю_{1}^{3}\right)$, относительно глубоководной (георгиевская свита) и глубоководно-морской - баженовская свита.

Нижневасюганская подсвита и баженовская свита относятся к региональным флюидоупорам, уверенно выделяются по данным промысловой геофизики (КС, ПС, ГК) по всему фонду скважин на месторождении, представляют реперы, между которыми заключен продуктивный горизонт $Ю_{1}$. 


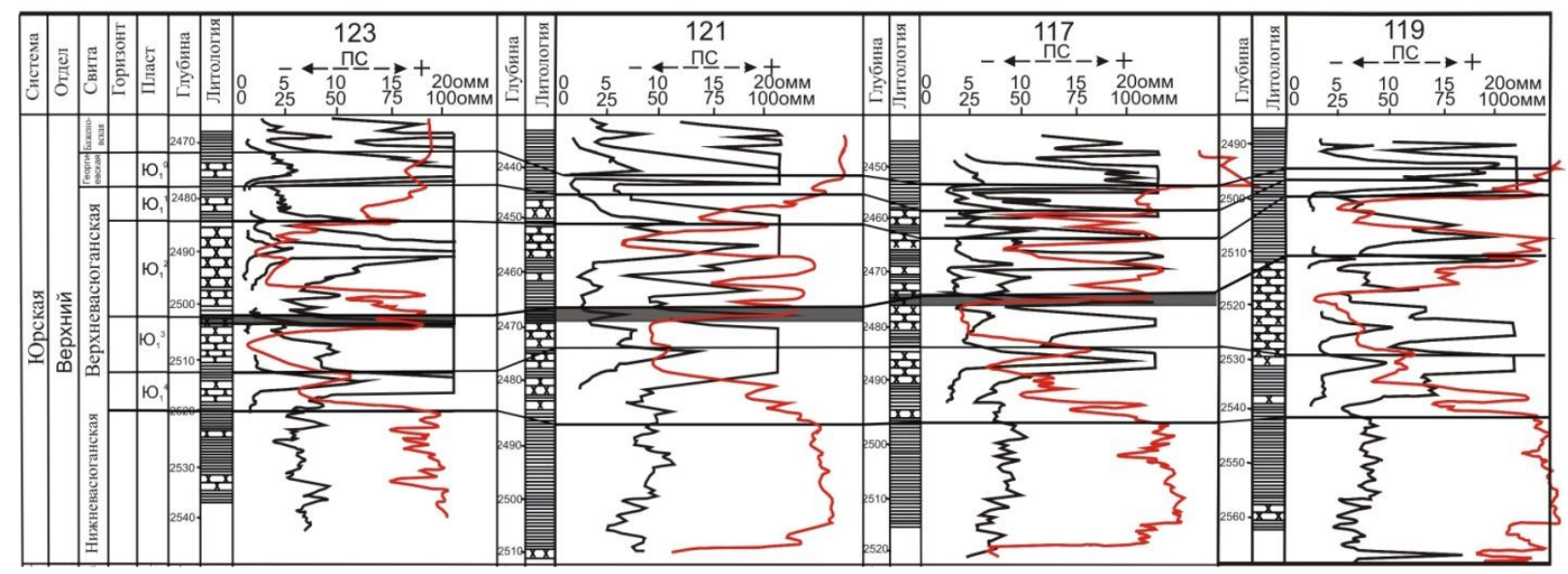

Рис. 3. Схема корреляции продуктивных отложений по линии I-I

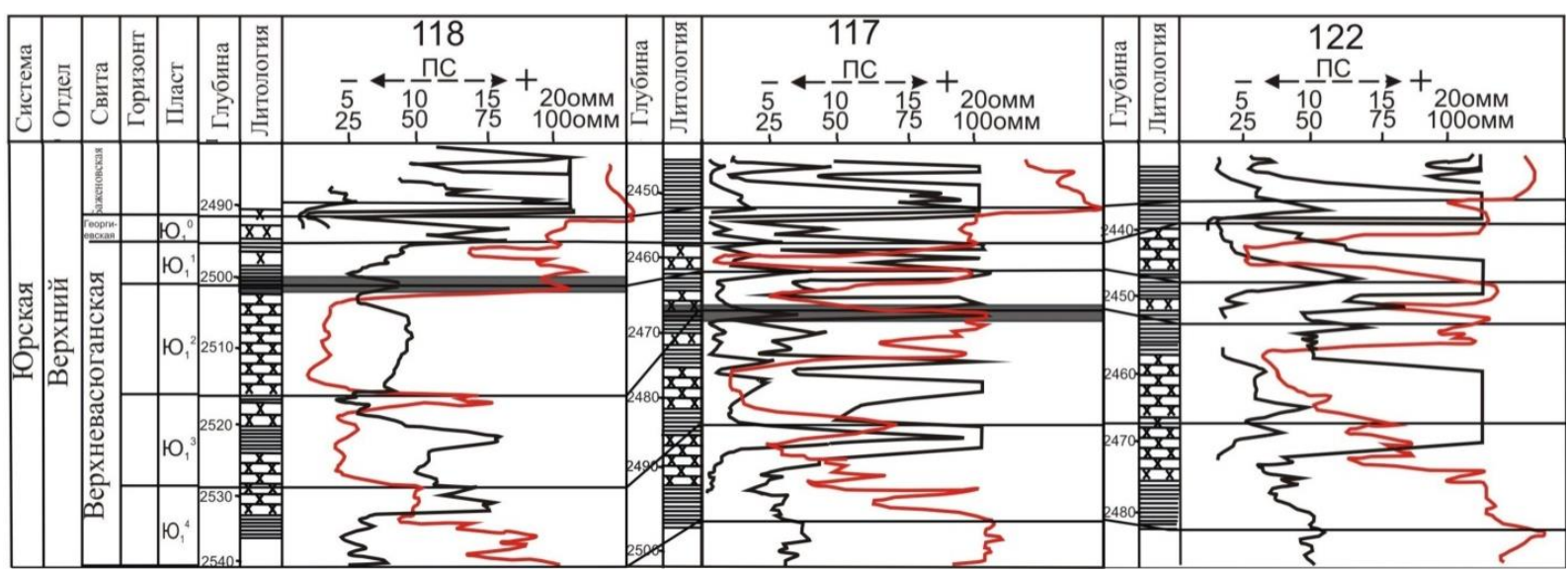

Рис. 4. Схема коррелящии продуктивных отложений по линии II-II

Пласт $Ю_{1}^{4}$ является базальным в горизонте $Ю_{1}$ и верхневасюганской подсвите. Он залегает на отложениях нижневасюганской подсвиты согласно, сформирован во время келловейской регрессии, распространён на всей территории месторождения, имеет мощность 10-12 м, представлен переслаиванием тёмно-серых глин и мелкозернистых песчаников, зернистость которых увеличивается вверх по разрезу. В кровле он сменяется глинистыми породами незначительной мощности (в скважине $123-1,5 \mathrm{M}$ ).

Пласт $Ю_{1}^{3}$ представлен переслаиванием серых мелкозернистых песчаников с кальцитовым и глинистым цементом, вверх по разрезу постепенно сменяющихся алевролитами, глинистыми и углистоглинистыми породами, содержащими пи- рит, и регионально выдержанным реперным пластом $\mathrm{У}_{1}$.

Пласт $Ю_{1}^{2}$ сформирован в оксфордское время и залегает несогласно на угле $\mathrm{V}_{1}$. Он представлен переслаиванием тёмносерых глин и светло-серых алевролитов и песчаников, распространенных в верхней части толщи, иногда (в скважинах 118 и 123 ) - только песчаниками. Мощность отложений с севера на юг меняется от 10 до 15 , с запада на восток - от 6 до 16 м.

Пласт $Ю_{1}{ }^{1}$ также сформирован в оксфордскую трансгрессию. Он распространён на всей территории месторождения и имеет мощность с севера на юг 5-8, а с запада на восток 6-9 м. Он сложен серыми с бурым оттенком среднезернистыми с глинистым цементом нефтенасыщенными песчаниками, в кровле - алевролитами и глинами, содержащими пирит. Отложения 
перекрываются глинистыми породами георгиевской свиты.

Разрез верхнеюрских отложений заканчивается темно-серыми, почти черными битуминозными аргиллитами баженовской свиты. На территории Малореченского месторождения баженовская свита вскрыта всеми пробуренными скважинами. В разрезе отмечаются прослои и линзы известняков (до 0,1 м). Породы практически непроницаемы и являются региональной покрышкой для продуктивного горизонта $Ю_{1}$. Свита уверенно выделяется по данным промысловой геофизики (КС, ПС, ГК) по всему фонду скважин. Характерной особенностью аргиллитов баженовской свиты является большое количество пирита [3].

\section{2. Строение разреза и особенности пород}

Строение разреза и особенности пород показаны на литологической колонке на основании макроскопического описания керна (скважина 124) (рис. 5). Снизувверх по разрезу последовательно описаны нижневасюганская подсвита, пласт $Ю_{1}{ }^{4}$, пласт $Ю_{1}{ }^{3}$, пласт $Ю_{1}{ }^{2}$, пласт $Ю_{1}{ }^{1}$, георгиевская свита и баженовская свита.

Нижневасюганская подсвита сложена глинами тёмно-серыми слабоалевритистыми с тонкими линзовидными прослойками светло-серых алевролитов, создающих пологонаклонную параллельную слоистость. Слойки алевролитов образуют серии под углом $15-20^{\circ}$ к оси керна, внутри серий тонкие слоечки и линзочки алевролита образуют почти горизонтальную слоистость, т. е. в целом наблюдается своеобразная тонкая косая слоистость.

Пласт $Ю_{1}^{4}$ представлен чёрными углистыми глинами и мелкозернистыми песчаниками, зернистость которых увеличивается вверх по разрезу. Встречаются также прослои карбонатизированного песчаника (около 0,1 м). Иногда отмечаются своеобразные следы жизнедеятельности донных животных, норки спирор- бисов [3]. В песчаниках встречаются включения сидерита в виде мелких (около $1 \mathrm{~cm})$ желваков и пятен $(2 \times 3 \mathrm{~cm})$.

Пласт $Ю_{1}^{3}$ представлен переслаиванием серых мелкозернистых песчаников с кальцитовым цементом, с тонкими прерывистыми прослойками углистослюдистого материала, создающими нечетко выраженную косую прерывистую слоистость и мелкозернистых песчаников с глинистым цементом, в которых также присутствуют редкие прослои углистослюдистого материала.

Вверх по разрезу песчаники постепенно сменяются серыми глинами слабоалевритистыми с редкими тонкими прослойками светло-серого алевролита, с послойно распределенным углистым детритом. Отмечаются отпечатки и обугленные остатки флоры. Вверху слоя в породах наблюдаются стяжения пирита.

Пласт $y_{1}$ представлен чёрными блестящими углями.

Пласт $Ю_{1}^{2}$ - переслаиванием тёмносерых глин и светло-серых алевролитов. В них отмечается косая, косоволнистая, пологонаклонная слоистость, иногда нарушаемая оползанием, затеками алевролитового материала в глину. Отмечаются включения линзообразных конкреций пирита с размером в поперечнике $0,8 \times 4 \mathrm{~cm}$, расположенных по наслоению. По плоскостям наслоения также отмечаются скопления углефицированного растительного детрита.

Пласт $Ю_{1}^{1}$ сложен буровато-серыми нефтенасыщенными мелко- и среднезернистыми с сидеритовым цементом песчаниками, содержащими углефицированный растительный детрит, который образует прерывистые горизонтальные прослойки.

Георгиевская свита сложена тёмно-серой глиной алевритистой, с мелкими стяжениями пирита, с прослоями тёмно-серых известняков и включениями ихтиодетрита. Содержание глинистого материала в разрезе увеличивается в направлении снизу вверх. 


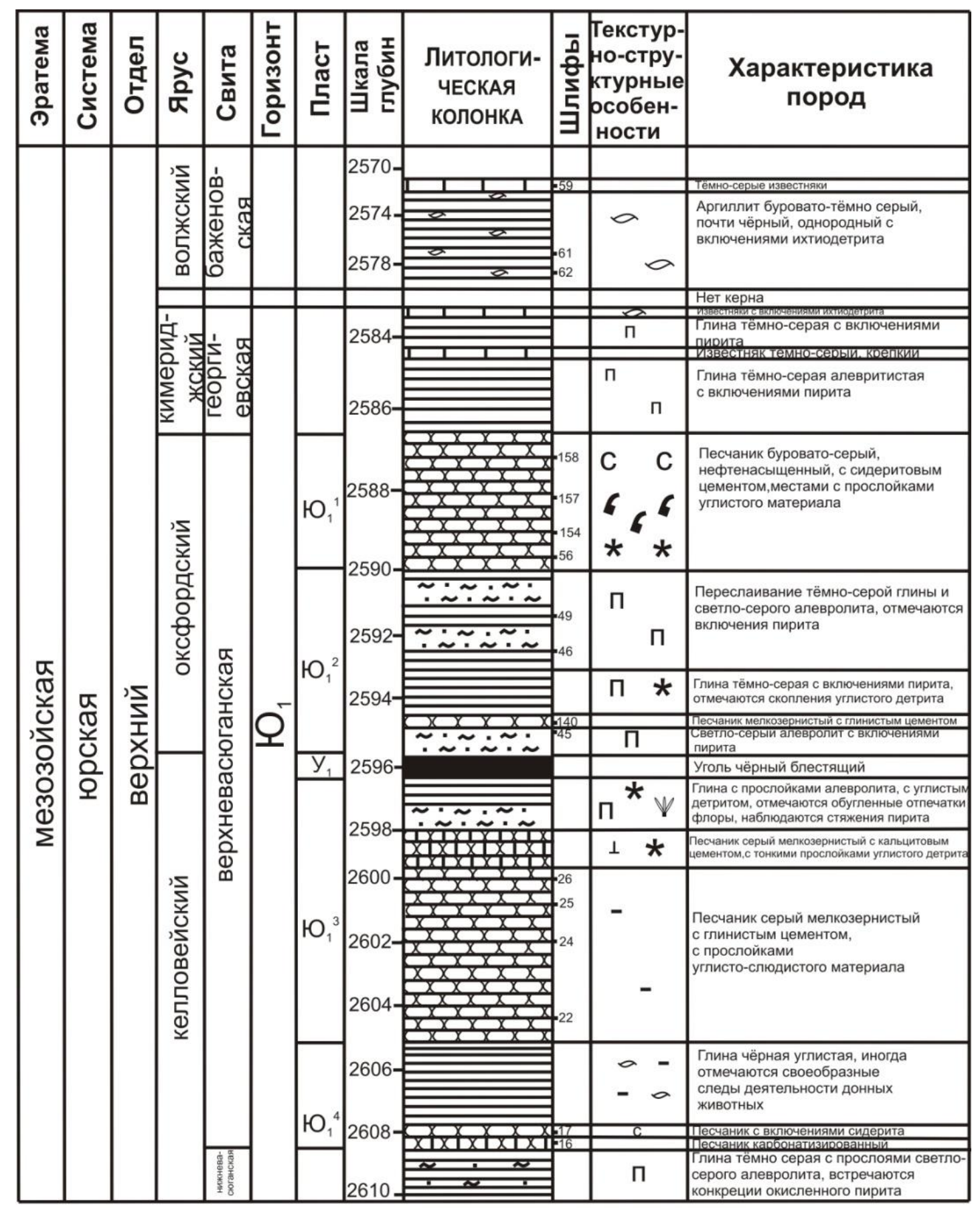

Условные обозначения

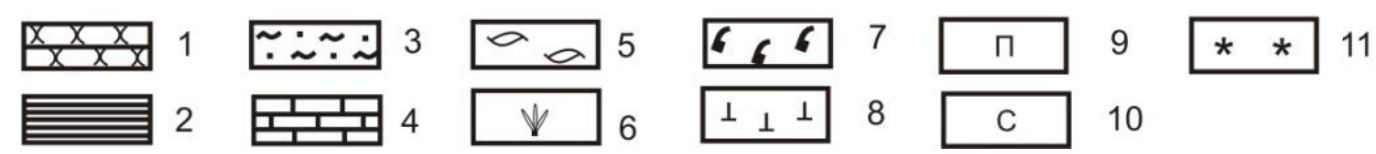

Рис. 5. Литолого-стратиграфическая колонка горизонта Ю $Ю_{1}$ 1 - песчаники, 2 - аргиллиты, 3 - алевролиты, 4-известняки, 5-зоогенный детрит, 6-флора, 7 - нефтенасыменность, 8 кальцитизация, 9 -пирит, 10 - сидерит, 11 - углистьй детрит

Баженовская свита представлена аргиллитами буровато-тёмно-серыми почти чёрными однородными с включениями ихтиодетрита, онихитами и рострами белемнитов. В разрезе отмечаются про- слои и линзы известняков (до 0,1 м). Породы практически непроницаемы и являются региональной покрышкой для продуктивного горизонта $Ю_{1}[2,8]$. 


\section{3. Петрографические особенности песчаных пород верхнеюрских отложений}

Пласт $Ю_{1}{ }^{4}$ на месторождении вскрыт в интервале 2609-2607 м.

Породообразующие минераль песчаников представлены кварцем и полевыми шпатами (рис. 6).

Квари представлен слабоокатанными обломками неправильной удлиненной и изометричной формы. Погасание зерен обычное, волнистое. Изредка наблюдается регенерация до образования кристалло-

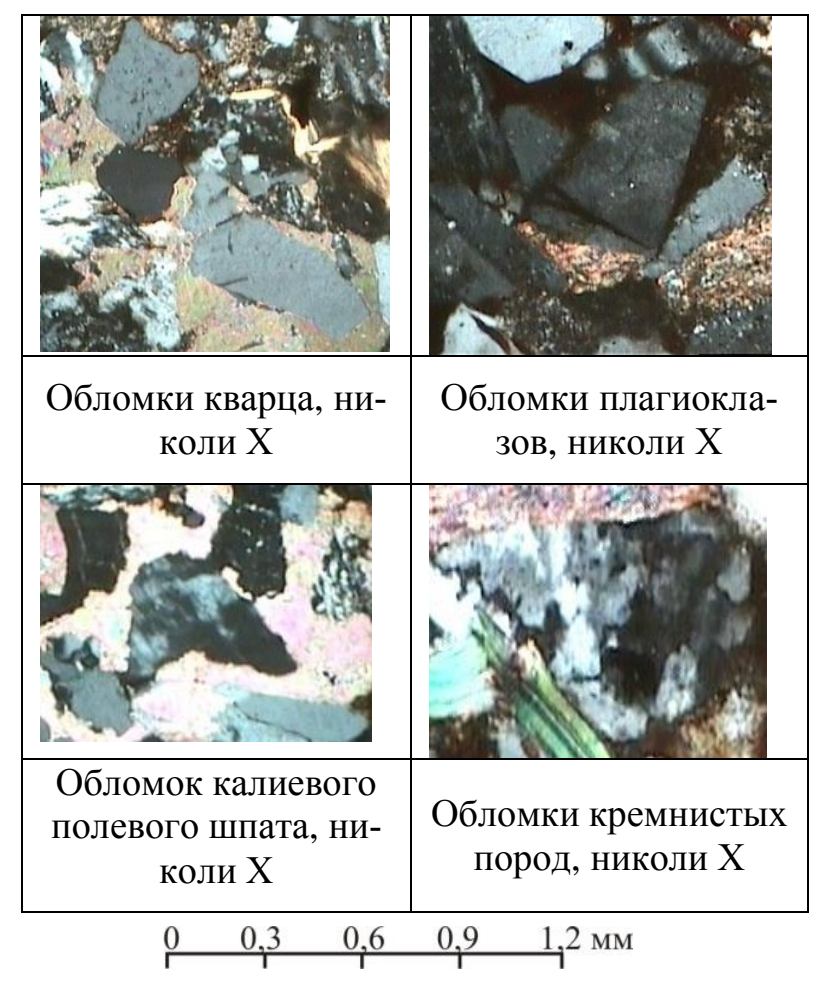

Рис. 6. Породообразующие минералы песчаников пласта ${ }_{1}^{4}$

графических элементов: граней и ребер, особенно на контакте с кальцитовым цементом. Края обломков корродированы.

Полевые шиаты представлены плагиоклазами и калиевыми полевыми шпатами, имеют изометричные и близкие к правильным четырехугольным формам разрезы. Плагиоклазы тонко сдвойникованы и не сдвойникованы, обладают хорошо выраженной спайностью, параллельной или под углом $87^{\circ}$. Часть зерен замещена серицитом (тонкочешуйчатым мусковитом) и кальцитом. Калиевые полевые шпаты представлены ортоклазом пертитового строения и микроклином с решетчатым двойникованием. В зернах наблюдаются трещины спайности, иногда они проявлены под углом $90^{\circ}$. Зерна ортоклаза часто замещены пелитом (смесью глинистых минералов) и кальцитом.

Второстепенные минералы представлены биотитом, мусковитом и хлоритом (рис. 7).

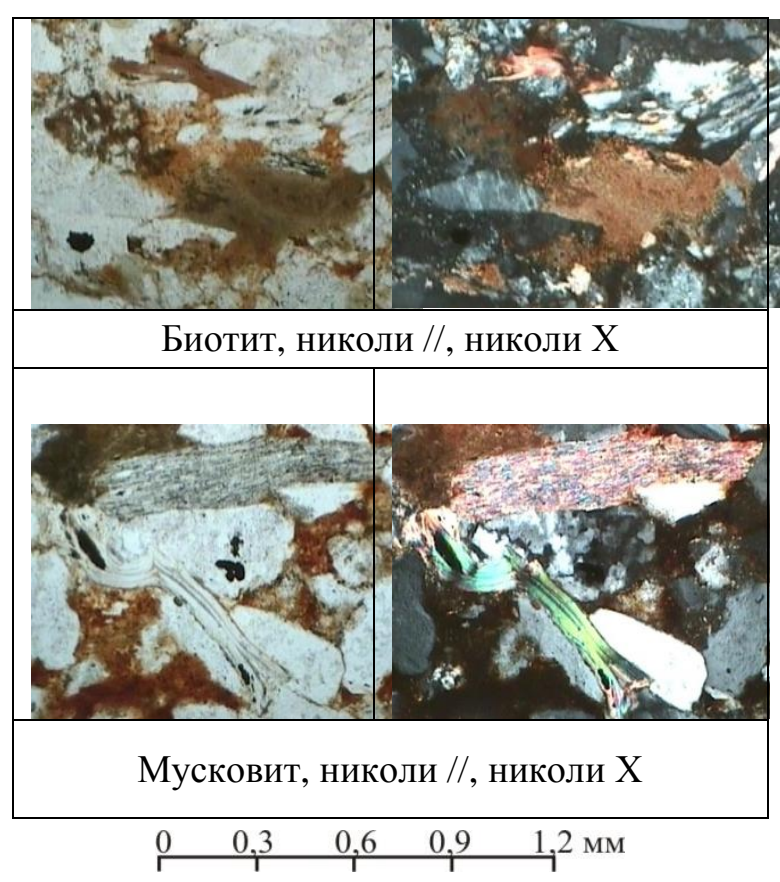

Рис. 7. Второстепенные минераль песчаников пласта $\mathrm{O}_{1}{ }^{4}$

Биотит встречается в виде обломанных удлиненных пластинчатых зерен разных размеров, имеет зеленовато-бурую окраску с плеохроизмом от желтозеленого до коричнево-бурого цвета. Спайность минерала совершенная, что выражено в тонких параллельных трещинках, протягивающихся через все зерно. В скрещенных николях минерал имеет высокую интерференционную окраску. Иногда биотит замещен хлоритом, сидеритом, кальцитом.

Мусковит представлен бесцветными удлиненными пластинками с совершенной спайностью и очень высокой интерференционной окраской. 
Хлорит встречается в виде деформированных пластинчатых зерен зеленого цвета. В скрещенных николях он имеет низкую интерференционную окраску.

Акцессорные минераль представлены цирконом.

Циркон встречен в единичных зёрнах. Минерал хорошо сохранил свои кристаллографические особенности. Зерна бесцветны, имеют призматическую форму, высокий рельеф и высокие цвета интерференции (рис. 8).

Цемент порового типа, в кальцитизированных песчаниках - базально-поровый пойкилитового типа (крупные кристаллические зерна кальцита включают обломки минералов и пород), в участках регенерации кварцевых зерен развит контурный цемент (рис. 9).

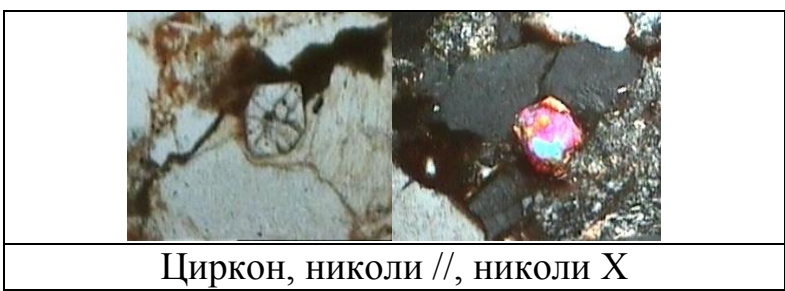

$$
\begin{array}{lllll}
0 & 0,3 & 0,6 & 0,9 & 1,2 \\
\hline & \text { мм }
\end{array}
$$

Рис. 8. Акиессорный циикон песчаников плаcma $Ю_{1}^{4}$

\section{Пустотно-поровое пространство} представлено в основном межзерновыми порами, а также внутризерновымми порами и микропорами в каолинитовом цементе. В карбонатизированных песчаниках поровое пространство отсутствует.

Признаки нефтенасыщения присутствуют в межзерновых порах и во внутризерновых порах (рис. 10) [4].

\section{Заключение}

Горизонт Ю 1 неоднороден, состоит из песчаных пластов, которые можно проиндексировать как $Ю_{1}{ }^{4}, Ю_{1}{ }^{3}, Ю_{1}{ }^{2}, Ю_{1}{ }^{1}$ и $\mathrm{O}_{1}{ }^{0}$. Пласты хорошо выделяются на каротаже, где-то происходит их слияние, а гдето они, наоборот, разделяются в основном глинистыми и глинисто-углистыми пропластками.
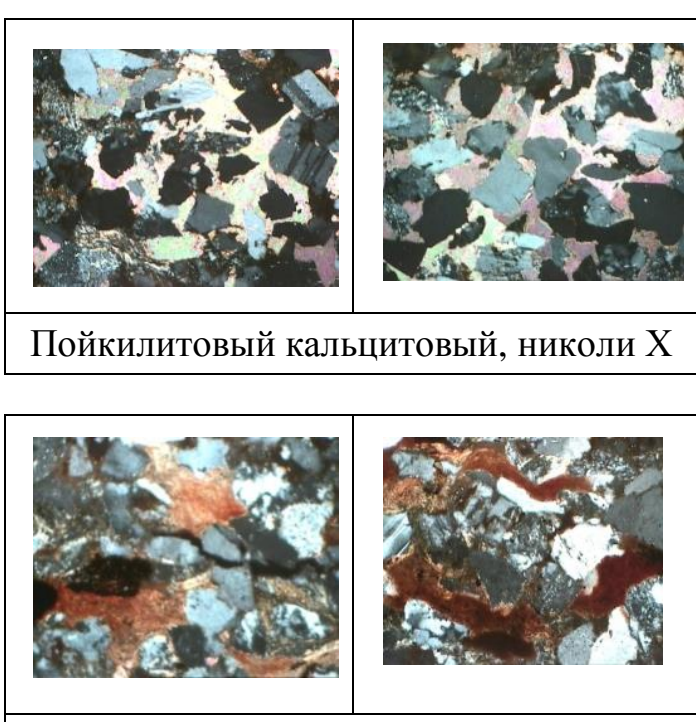

Базально-поровый сидеритовый, контактный и контурный пиритовый, николи $\mathrm{X}$

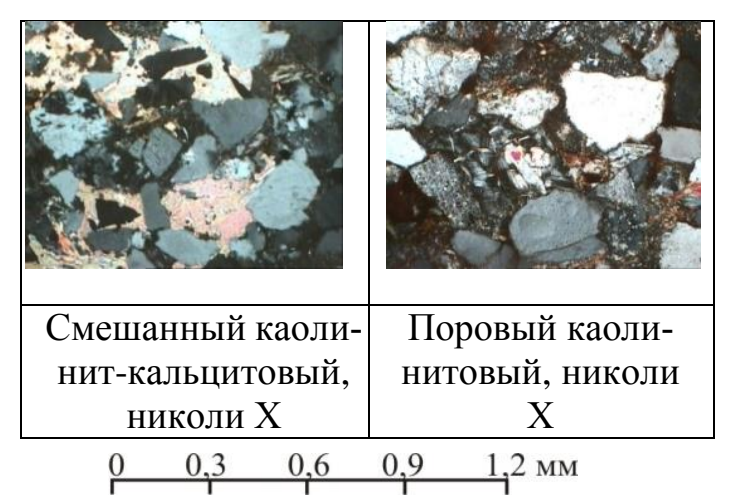

Рис.9. Типы цемента песчаников пласта $Ю_{1}{ }^{4}$

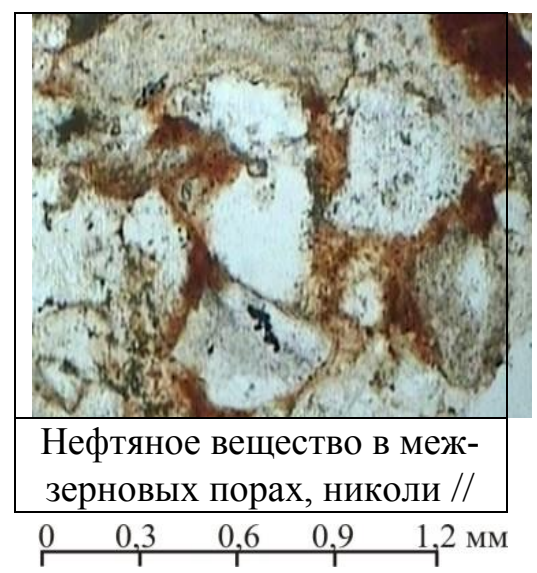

Рис. 10. Нефтенасыщенность песчаников пласта $\mathrm{O}_{1}^{4}$

По вещественно-структурному составу коллекторы однотипные, отличаются в деталях. Коллекторы имеют кварц- 
полевошпатовый состав, а также много кремнистых и кремнисто-слюдистых агрегатов. Второстепенные минералы представлены слюдами (мусковитом, биотитом) и хлоритом. Акцессорные минералы - цирконами. Цемент в основном каолинитовый, сидеритовый, пиритовый и кальцитовый. Пустотно-поровое пространство представлено в основном межзерновыми, внутризерновыми порами и микропорами в каолинитовом цементе. Песчаники пластов $\mathrm{O}_{1}{ }^{4}$ пропитаны нефтяным веществом $[9,10]$.

Породы-флюидоупоры верхневасюганской подсвиты представлены алевролитами мелкозернистыми глинистыми и глинами. Поры в них отсутствуют или мелкие, изолированные. Флюидоупоры баженовской свиты представлены аргиллитами битуминозными с прослоями и линзами известняков.

\section{Библиографический список}

1. Брадучан Ю. В., Гурари Ф. Г., Захаров В. А. $u \partial p$. Баженовский горизонт Западной Сибири (стратиграфия, палеогеография, экосистема, нефтеносность). Новосибирск: Наука, 1986. 217 с.

2. Гараев А.Р. Модели осадконакопления неокомского комплекса ЗападноСибирского мегабассейна // Нефтяное хозяйство. 2014. №2. С. 97-99.
3. Гутман И.С., Султаншина Т.Р., Халяпин $C . B$. Особенности строения залежей нефти в горизонте $\mathrm{FC}_{1}$ Грибного месторождения // Нефтяное хозяйство. 2013. №5. С. 60-64.

4. Ежова А.В. Литология: практикум для выполнения учебно-научных работ студентами направления «Прикладная геология». Томск: Изд-во «Красное знамя», 2008. 72 с.

5. Каламкаров Л. В. Нефтегазоносные провинции и области России и сопредельных стран. М.: Изд-во «Нефть и газ», 2003. 558 c.

6. Недоливко Н. М., Ежова А. В. Петрографические исследования пород-коллекторов: учебное пособие. Томск: Изд-во ТПУ, 2010. $158 \mathrm{c}$.

7. Сурков В.С., Жеро О.Г. Фундамент и развитие платформенного чехла ЗападноСибирской плиты. М.: Недра, 1981. 143 с.

8. Шмырина В.А., Морозов В.П., Бахтин А.И. Седиментологические и литогенетические факторы, определяющие коллекторские свойства терригенных пород // Нефтяное хозяйство. 2014. №10. С. 18-20.

9. Hoek E., Brown E.T. Empical strength criterion for rock masses // J.Geotechn.Engeng. (ASCE). 1980. Vol.106. P.1013-1035.

10.Kaufman J., Jamenson J. Sequence stratigraphy, facies, and reservoir quality of lower Devonian carbonates in Roman Trebsa field, Timan-Pechora basin, C.I.S. // SERM Spetial publication. 2002. Vol.74. P.43-68. 


\section{Lithologic Characteristics of the Productive Unit Yu1 of the Malorechenskiy Oil Field (Tomsk Region)}

\section{S.Kh. Beshleev ${ }^{\text {a }}$, O.E. Kochneva ${ }^{b}$}

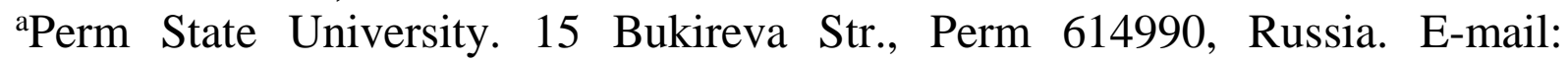
selim.beshli@gmail.com

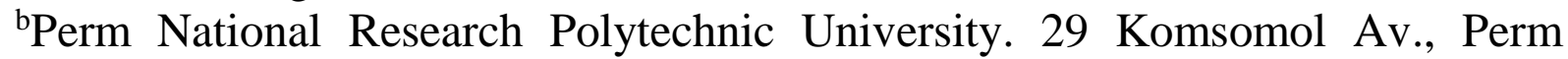
614990, Russia. E-mail: kochnevaoe@ mail.ru

This article presents the results of study of the geological structure of the Malorechenskoye oil field and the production unit Yu1. The variation of the lithological composition and petrographic characteristics of the Upper Jurassic sediments at the area was considered. Interpretation of the borehole logging data showed that the inhomogeneous productive unit Yul is composed of several interbedded layers. Locally, these beds are bounded with predominantly clayey and clay-carbonaceous layers.

Keywords: productive layer, correlation, oil saturation, petrography, analysis.

\section{References}

1. Braduchan Ju.V., Gurari F.G., Zakharov V.A. et al. 1986. Bazhenovskiy gorizont Zapadnoy Sibiri (stratigrafiya, paleogeografiya, ekosistema, neftenosnost). [Bazhenovskiy horizon of Western Siberia (stratigraphy, paleogeography, ecosystem, oil content)]. Novosibirsk, Nauka, p. 217. (in Russian)

2. Garaev A.R. 2014. Modeli osadkonakopleniya neokomskogo kompleksa ZapadnoSibirskogo megabasseyna [Depositional model of the Neocomian complex of West Siberian Megabasin]. Neftyanoe khozyaystvo. 2:97-99. (in Russian)

3. Gutman I.S., Sultanshina T.R., Khalyapin S.V. 2013. Osobennosti stroeniya zalezhey nefti v gorizonte YuC1 Gribnogo mestorozhdeniya [Structural features of oil reservoirs in horizon YuC1 Gribnoe field]. Neftyanoe khozyaystvo. 5:60-64. (in Russian)

4. Ezhova A.V. 2008. Litologiya. Praktikum dlya vypolneniya uchebno-nauchnykh rabot studentami napravleniya "Prikladnaya geologiya". [Lithology. Notes for implementation of practical training of students scientific works on the course "Applied Geology"]. Tomsk, JSC Publishing house "Red flag", p. 72. (in Russian)

5. Kalamkarov L.V. 2003. Neftegazonosnye provintsii i oblasti Rossii i sopredelnykh stran [Oil and gas provinces and region of Russia and adjacent countries]. Moskva, Neft i gaz, p. 558. (in Russian)
6. Nedolivko N.M., Ezhova A.V. 2010. Petrograficheskie issledovaniya porod-kollektorov [Petrographic studies of reservoir rocks] Tomsk, Publ. House TPU, p. 158. (in Russian)

7. Surkov V.S., Zhero O.G. 1981. Fundament i razvitie platformennogo chekhla ZapadnoSibirskoy plity. [Basement and development of the platform mantle of the West Siberian Plate]. Moskva, Nedra, p. 143. (in Russian)

8. Shmyrina V.A., Morozov V.P., Bakhtin A.I. 2014. Sedimentologicheskie i litogeneticheskie faktory, opredelyayushchie kollektorskie svoystva terrigennykh porod [Sedimentological and lithogenetic factors determining reservoir properties of terrigenous rocks]. Neftyanoe khozyaystvo, 10:18-20. (in Russian)

9. Hoek E., Brown E.T. 1980. Empical strength criterion for rock masses. J. Geotechn. Engin. Div. (ASCE). 106:1013-1035.

10. Kaufman J., Jamenson J. 2002. Sequence stratigraphy, facies, and reservoir quality of lower Devonian carbonates in Roman Trebsa field, Timan-Pechora basin, C.I.S. In Paleozoic Carbonates of the Commonwealth of Independent States (CIS). W.G. Zempolich and H.E. Cook Eds. 74:43-68. doi: 10.2110/pec.02.74.0043 